\title{
Helen Salisbury: Ageing and inequality
}

\author{
Helen Salisbury GP
}

Oxford

"Don't get old, doctor," my patients often advise me. However, we always end up agreeing that the alternative is worse. When patients in their 90s complain that they can no longer manage the two mile walk into town and the two miles back without their knees hurting, I try to avoid any "so wonderful for your age" comments, which they must hear repeatedly. Instead, we discuss painkillers and why they probably don't need surgery yet. These patients are impressive women (and the occasional man), often caring for others and being lynchpins of the community.

If you work in a hospital you'll be surrounded by ill patients who are mostly old, and most of those you meet in their 80s and 90 s will be frail and suffering. It's a revelation for some hospital doctors to spend time in a GP surgery, to redress this dismal equation of old age with decrepitude. In primary care we don't see some of the older people on our list until we invite them for a flu vaccination or blood pressure check. They're not taking any medicines and have no need of our services.

I'd like to emulate them, to be active and purposeful for decades after retirement, so I pay attention: what can I do to be like them? There are no great revelations. First, I must avoid inheriting early cancer genes and high cholesterol. I should follow this with a lifetime of not smoking, ${ }^{1}$ drinking moderately or not at all, ${ }^{2}$ and staying active. ${ }^{34}$ If I do need medical care I should try to see the same doctor on each visit to the GP surgery or hospital clinic, as continuity of care may contribute to my longevity. ${ }^{5}$

Above all, I should be careful not to be poor: there's a 19 year difference in healthy life expectancy between the most and least deprived areas of the UK, and the worst off can expect to live a third of their life in poor health. ${ }^{6}$ How poverty makes people ill is a matter of debate: what proportion is due to poor diet, smoking, or the constant stress of struggling to keep a roof over your head and food on the table? But the relation between poverty and earlier disability and death is undeniable-it's clear from the literature, and it's evident in my waiting room.

If the government really wants to reduce health inequalities, as proclaimed by NHS England in its long term plan, ${ }^{7}$ perhaps the Department of Health and Social Care should have a word with the Department for Work and Pensions. We urgently need to reverse the deep cuts to social welfare that have resulted in a dramatic rise in poverty and destitution since $2013^{8}$ - and, with it, a widening gap between the lives of rich and poor people.

Competing interests: See www.bmj.com/about-bmj/freelance-contributors.

Provenance and peer review: Commissioned; not externally peer reviewed.

$1 \quad$ NHS Digital. Statistics on smoking-England, 2018 [PAS]. 3 Jul 2018. https://digital.nhs. uk/data-and-information/publications/statistical/statistics-on-smoking/statistics-on-smokingengland-2018/part-1-smoking-related-ill-health-and-mortality.

2 Wood AM, Kaptoge S, Butterworth AS, etal. Emerging Risk Factors Collaboration/EPIC-CVD/UK Biobank Alcohol Study Group. Risk thresholds for alcohol consumption: combined analysis of individual-participant data for 599912 current drinkers in 83 prospective studies. Lancet 2018;391:1513-23. https://www.thelancet.com/journals/ lancet/article/PIIS0140-6736(18)30134-X/fulltext. 10.1016/S0140-6736(18)30134-X 29676281

3 Reimers CD, Knapp G, Reimers AK. Does physical activity increase life expectancy? A review of the literature. J Aging Res 2012;2012:243958. https://www.ncbi.nlm.nih.gov/ pmc/articles/PMC3395188/. 10.1155/2012/243958 22811911

4 Cheng S. How sure are we that physical activity makes us live longer? Br J Sports Med 2018 Mar 20. https://blogs.bmj.com/bjsm/2018/03/20/how-sure-are-we-that-physicalactivity-makes-us-live-longer/.

5 Pereira Gray DJ, Sidaway-Lee K, White E, Thorne A, Evans PH. Continuity of care with doctors-a matter of life and death? A systematic review of continuity of care and mortality. BMJ Open 2018;8:e021161. https://bmjopen.bmj.com/content/8/6/e021161. 10.1136/bmjopen-2017-021161 29959146

6 Raleigh V. What is happening to life expectancy in the UK? King's Fund. 22 Oct 2019. https://www.kingsfund. org.uk/publications/whats-happening-life-expectancy-uk.

$7 \quad$ NHS England. NHS Long term plan—chapter 2: More NHS action on prevention and health inequalities. Jan 2019. https://www.longtermplan.nhs.uk/online-version/chapter-2more-nhs-action-on-prevention-and-health-inequalities/.

8 Butler P. More than $4 \mathrm{~m}$ in UK are trapped in deep poverty, study finds. Guardian 2019 Jul 29. https://www.theguardian.com/society/2019/jul/29/uk-deep-poverty-study-austerity.

Published by the BMJ Publishing Group Limited. For permission to use (where not already granted under a licence) please go to http://group.bmj.com/group/rights-licensing/ permissions 